\title{
Analysis on Utilizing L1 in ESL Speaking Class for College ESL Learners
}

\author{
Siqi Song
}

\begin{abstract}
The use of learners' native language (L1) in the ESL classroom has been an unfailing topic for arguments over time. Motivated by studies and notions that $\mathrm{L1}$ facilitates and promotes L2 learning, this paper examines utilizing L1 in learning activities of an English speaking class in a university in China. The paper touches upon issues about using $\mathrm{L} 1$ from the perspective of both teachers and students, and relates $L 1$ with students' identity and teachers' teaching efficiency. It concludes that $\mathrm{L} 1$ plays a positive role in the case of this lower proficiency English speaking class, as it leads to active class participation via identity construction, and improves teaching efficiency through instructional languages.
\end{abstract}

Index Terms - Using L1, identity construction, instructional language.

\section{INTRODUCTION}

Language is best learned through using it [1]-[3], that is, second language learners need to be exposed to the target language and provide their own L2 inputs as much as possible. With the notion that learning is most effective when students are emerged in the target language environment to use it for all sorts of negotiations of meaning and meaningful communication, the popular idea is that English-only class is recommended for ESL learners.

Initially, I decided to apply the English-only policy to my ESL speaking class in order to increase the target language production, and promote meaningful communication in L2. However, along with the reduction of Chinese utterances was the decrease of target language production of some learners. I found myself trapped in the dilemma of creating an immersive language learning experience and dismantling their interior insecurity in the sudden exposure to the target language. The use of learners' native language in the ESL classroom has been an unfailing topic for arguments over time. There are advocators of a monolingual language class, who suggested that L1 could impede learners' potential practice and input in target language and hinder learning [4], [5]. Some scholar and educators, however, believed that L1 facilitates L2 learning and improves efficiency [6]-[9]. The "whether-or-not question" of L1 often requires alertness and flexibility from the teachers' part so as to reach a contextualized decision. Thus, to look upon the question of L1 in ESL learning, this papers explored questions about using L1 in speaking activities in a college English speaking and listening class.

The targeted class described in this paper was a college

Manuscript received September 24, 2016; revised December 11, 2016.

Siqi Song is with the Hubei University of Technology, Wuhan, China (e-mail: qiqisally_7@hotmail.com).
English listening and speaking class in a University in China. (This paper would concentrate on the speaking part) Students were 27 freshmen (All names appeared in the paper were pseudonymous names) majoring in Art Design, with relatively poor English foundation and lower proficiency. The class met once a week for 90 minutes in the spring semester of 2016, and it lasted for 14 weeks. To address the issue on utilizing L1, the paper will look closely at learning activities in the target class, and examine the role of L1 in the perspective of both learner and teacher.

\section{L1 AS LEARNERS' LANGUAGE CHOICE AND IDENTITY}

Gibson stated that "Language-both code and content-is a complicated dance between internal and external interpretations of our identity. [10]" Or as Norton pointed out from a sociolinguistic perspective, people's identities are shaped by the language they use [11]. Thus, Cross-linguistic resources from native language, which was Chinese, were included in this class as to trigger translanguaging device in language learning. A close analysis of the patterns of learners' classroom interaction revealed some insightful depiction of how language and identity are potentially associated.

Eckert and McConnell-Ginet defined "community of practice" as groups "whose joint engagement in some activity of enterprise is sufficiently intensive to give rise over time to a repertoire of shared practices" [12]. According to this definition, "certain linguistic practices are understood by the members to be more appropriate than others" [13]. Therefore, learners are highly inclined to communicate with each other in the linguistic medium that agrees with their shared identity. This statement also found its way among individual interactions.

During group discussions, Connie, the most advanced learner who was quite capable of engaging in English conversations in class, was often the group leader. Her reactions to her group members varied much regarding what others said. She responded in Chinese while another student spoke to her in Chinese, but reacted in English when someone made a suggestion to her in English. (See Table I) Student's choice of language was reflective of her self-perception of her identity in this conversation. Linguistic codes were used as identity markers with the intention to be recognized and accepted by members of speech community.

TABLE I: RECORDS OF STUDENTS' INTERACTIONS IN A GROUP DISCUSSION ABOUT FAVORITE JOBS

\begin{tabular}{|l|l|}
\hline Students' comments & Connie's response \\
\hline Lille: Connie, 你觉得这里面哪个 & Connie: 第一个, 美食家(the \\
职业最有趣?(which do you think is & first one, a food expert) \\
\hline
\end{tabular}




\begin{tabular}{|l|l|}
\hline $\begin{array}{l}\text { the most interesting job among } \\
\text { these) }\end{array}$ & \\
\hline $\begin{array}{l}\text { Tom: What do you think of this } \\
\text { description of being a farmer? He } \\
\text { owns a yard, oh this house looks } \\
\text { big. }\end{array}$ & $\begin{array}{l}\text { Connie: I heard that farmers in } \\
\text { western countries are rich. It is } \\
\text { a good job. }\end{array}$ \\
\hline $\begin{array}{l}\text { Cindy: my favorite job among these } \\
\text { is play-writer. I want to write } \\
\text { interesting stories about people's } \\
\text { life. And you? }\end{array}$ & $\begin{array}{l}\text { Connie: I want to be a food } \\
\text { expert, I like eating delicious } \\
\text { food }\end{array}$ \\
\hline
\end{tabular}

With the attempt to establish the rapport with learners and create a congenial language environment, I experimented with the construction of a flexible multilingual community of practice by initiating the topic of the conversation in English, and the class would respond either in English or in Chinese, or in a mixture of different linguistic codes (See Table II).

TABLE II: RECORDS OF SELECTED LINGUISTIC CODES IN CLASS DISCUSSION ON OPEN-ENDED TOPICS

\begin{tabular}{|c|c|}
\hline Topic of conversation & Students' discussion \\
\hline $\begin{array}{l}\text { If there is a job offer that pays } \\
\text { really good salary, but is not related } \\
\text { to your interest or specialty, would } \\
\text { you take it? }\end{array}$ & $\begin{array}{l}\text { Connie: I would take the job. } \\
\text { Money is very important, and I } \\
\text { valued it a lot. With money, I could } \\
\text { open my own business after } \\
\text { working for a few years. } \\
\text { Sue: no, I want to do something I } \\
\text { like. I think interest is most } \\
\text { important, or I could feel bored. }\end{array}$ \\
\hline $\begin{array}{l}\text { Would you like to do graffiti on the } \\
\text { wall? }\end{array}$ & $\begin{array}{l}\text { Cathy: yes, doing graffiti is cool. } \\
\text { 我觉得很有个性特立独行.(I think } \\
\text { it is unique) } \\
\text { Cindy: 我去 L.A 的时候看到了好 } \\
\text { 多 graffiti(I saw lots of graffiti } \\
\text { when I went to LA), that was cool. } \\
\text { The graffiti is about many things. } \\
\text { 他们的画风很浮夸, 很有想象力 } \\
\text { (their style was very exaggerated, } \\
\text { very imaginative), I think that's part } \\
\text { of the culture. }\end{array}$ \\
\hline $\begin{array}{l}\text { What is your favorite day of the } \\
\text { year? }\end{array}$ & $\begin{array}{l}\text { Michael: my birthday. I get lots of } \\
\text { gifts. I can go to do some 疯狂的事 } \\
\text { 情(crazy things). } \\
\text { Jenny: 春节 (spring festival), our } \\
\text { family make 饺子 (dumpling), I } \\
\text { play 鞭炮(firework), and grandpa } \\
\text { write 对联(couplets) on the door. }\end{array}$ \\
\hline $\begin{array}{l}\text { Where do you want to go most for } \\
\text { vacation, without considering } \\
\text { money? }\end{array}$ & $\begin{array}{l}\text { Lillie: I want to go to London. } \\
\text { Because city center 很繁华(is very } \\
\text { prosperous), 那些历史古迹(those } \\
\text { historical relics), like Big Ben, the } \\
\text { London Bridge, the Westminster } \\
\text { church, are impressive. } \\
\text { Tom: I want to go to Japan, I like } \\
\text { 动漫(comics and cartoons), I want } \\
\text { to buy 原版漫画 (original comic } \\
\text { books) and meet my favorite } \\
\text { painter... }\end{array}$ \\
\hline
\end{tabular}

The linguistic codes used in students' language in discussion automatically reflected the self-perception of their identities as ESL learners with limited vocabulary and language proficiency, but willing to emerge into the English-speaking environment in their own way. Since that they tended to adopt the language that their identity most comfortably resides, and they are naturally willing to contribute more to the discussion. For instance, Lillie and Cindy loved watching American TV dramas and has been to English speaking countries for several times, the above records of their language reveal their self perception as someone who had rich knowledge about western cultures. In addition, Jenny, who was a volunteer Chinese teaching assistant for international students, usually used Chinese to replace some traditional vocabulary in Chinese such as “饺 子(jiaozi)” for dumpling, “春节(chunjie)" for Chinese new year, the Spring Festival, “鞭炮(bianpao)” for fireworks, etc. In this case, Jenny's language indicated her emphasis on Chinese culture, and her identity as a lover and practitioner of this culture. Besides, with the aid of L1, students overcame the obstacles of limited L2 knowledge, combining L1 with L2 helped the class join discussion more naturally with higher fluency, making them more confident as L2 users.

In all, every student in the class could participate in speaking and communication with inclusion of L1. The class became "a desired community that offers possibilities for an enhanced range of identity options in the future" [14], which was more active than a class solely in English. And students expressed their meaning more accurately and fluently, agreeing with the goal of building communicative competence. A relatively recent study on Hong Kong English and identity projects the pragmatic function of language that pertains to both identity and context [15]. Students' use of L1 in communication should not be simply viewed as a distraction from the English learning; on the contrary, the mixture of L1 and target language employed by the learners needs to be highlighted as a tactic to negotiate multiple identities across various social and linguistic communities.

\section{L1 AS TEACHER'S INSTRUCTIONAL LANGUAGE TO EFFECTIVE TEACHING}

Instructional language choice, like many other pedagogical decisions an ESL teacher needs to make, has crucial influence on how learners' will benefit from the learning process. With the knowledge that students receive little or no exposure to the target language due to living in the native language communities, it is better to create opportunities for learners to realize the target language knowledge in actual use. However, the insistence on English-exclusive during the classroom instruction and activities not only fail to engage learners' full participation in the learning at certain point, but even estrange them from this process.

It is often noticed that many students made similar structural mistakes such as in -WH questions. When the question inquired about past action or event, they tended to use the past tense auxiliary verb, as well as the past tense verb. For instance, they often produced sentences like "when did the man went to France?", "what did Mary said?" I tried to explain to them by saying that "“did' is an auxiliary verb here and the regular verb form is needed after the auxiliary verb". The response was silence and confusion.

Cummins stated that "Conceptual knowledge developed in one language helps to make input in the other language comprehensible" [16]. Many learners had already been familiar with the grammar rules, but only under the context 
of Chinese instruction; their lack of meta-language in English prevented them from transferring their prior knowledge to the current learning. When I heard students again make the same mistake, I changed the method by employing Chinese instruction, which led to student's immediate self-correction (See Conversation I):

\section{Student: "what did Tom said just now?" \\ Teacher: “助动词did后面要用动词的原型。”(regular verb form is used after auxiliary 'did'.) \\ Student: "so...what did Tom say just now?" \\ Teacher: "yes, exactly"(Teacher then wrote the sentence on the blackboard and highlighted and marked the form of 'did' and 'say' to summarize this rule.)}

\section{(Conversation I)}

Offering both oral and written grammar instruction in learners' L1 managed to mend the missing link of this knowledge loop, tapped into the common underlying foundation of language development [17], which made understanding easier and resulted in more efficient teaching in shorter time.

Besides explaining meta-language terms, L1 improves efficiency and proves to play positive role in open discussion activities as well. Adult learners (of lower language proficiency) may experience frustration trying to participate in discussions that require critical thinking in an English-only class when their linguistic ability of the target language is incompatible with their cognitive development [18]. During a lesson about "Arts" in week 6, I introduced a video program expressing opposite opinions towards graffiti on city walls and buildings. After watching, learners were asked to share their view towards the controversial topic of graffiti. Being aware of their limited English expression but rich ideas about arts which was their major of study, I invited them to contribute their ideas in either English or L1, and the whole class co-constructed the complete English sentences for answers given in Chinese. Without the constraint of limited English ability, students were able to relate the discussion not only to their personal experience, but also issues of criminal rate, personal property, artistic techniques, even critical comparison between China and the western history and culture on arts.

In addition, L1 could also be used to build some similar linguistic connections between L1 and target language. Garcia chose the term translanguaging over code-switching to capture the "language fluidity and movement" [19], [20]. When I invited students in an activity of finding different words with same meaning in British and American English, I code-switched while comparing the British and American English variation that often occurred in speaking with the dialectic variety in Chinese(See Conversation II):

Teacher: "People in the US and UK tend to adopt different words for the same thing. It's like different dialects in China. Like in my hometown, 我会把spoon叫“调美. (tiaogeng)”. 你们那怎么说啊? (We call a spoon tiaogeng. How do you say a spoon?)

Several students: 勺子(shaozi)

Jenny: It's like lift and elevator, bill and check, or chip and crisp, right?

(Conversation II)

After the example in translanguaing, students could actively generalize examples by themselves. As Hudelson and Faltis put it, "learners may react more positively to the new language if they experience acceptance and valuing of the native language" [21]. L1 linguistic codes enable students to engage in the active exploration of knowledge.

Therefore, "Having a large amount of meaningful L2 use does not preclude using the L1" [22]. Sharing an instructional language other than the target language offers extra options to enhance teaching efficiency, and promote the productive learning and input of learners. Despite the truth that the English classroom is one of the few opportunities for learners to practice communication in English, L1 should not be a taboo in the class.

\section{CONCLUSION}

Based on the analysis of target class, L1 did play a positive role in ESL speaking class. For one thing, mixture of L1 and target language builds a class community that embraces multiple choices of identity, and therefore, fosters active participation in learning; for another thing, L1 as an instructional language improves efficiency of class, and is a pedagogical method to facilitate learning activity. By saying this, I do not mean that students and teachers could rely on L1 to learn, but to use L1 as a tool to achieve better learning experience. It should be noted that the analysis is based on the target English class in college setting with lower proficiency students, therefore, different contexts may prefer different roles for $\mathrm{L} 1$, which needs constant observation of instructors and negotiation between teacher and students.

\section{REFERENCES}

[1] D. Freeman, Techniques and Principles in Language Teaching, Oxford: Oxford University Press, 2000.

[2] D. Willis and J. Willis, Doing Task Based Teaching, Oxford: Oxford University Press, 2007.

[3] J. Harmer, The Practice of English Language Teaching, Essex: Pearson Education Limited, 2007.

[4] S. Bouangeune, "Using L1 in teaching vocabulary to low English proficiency level students: A case study at the University of Laos," English Language Teaching Journal, vol. 2, no. 3, pp. 186-193, 2009.

[5] R. Ellis, Understanding Second Language Acquisition, Oxford University Press, 1985.

[6] D. Atkinson, "The mother tongue in the classroom: A neglected resource?" ELT journal, vol. 41, no. 4, pp. 241-247, 1987.

[7] P. Nation, "The role of the first language in foreign language learning," Asian EFL Journal, vol. 5, no. 2, pp. 1-8, 2003.

[8] J. Tang, "Using L1 in the English classroom," English Teaching Forum, vol. 40, no. 1, pp. 36-43, 2002.

[9] M. Swain and S. Lapkin, "Task-based second language learning: The uses of the first language," Language Teaching Research, vol. 4, no. 3, pp. 251-274, 2000.

[10] K. Gibson, "English only court cases involving the U.S. workplace: The myths of language use and the homogenization of bilingual worker's identities," Second Language Studies, vol. 22, no. 2, pp. $1-60,2004$.

[11] B. Norton, "Social identity, investment, and language learning," TESOL Quarterly, vol. 29, no. 1, pp. 9-31, 1995.

[12] P. Eckert and S. McConnell-Ginet, "New generalizations and explanations in language and gender research," Language in Society, vol. 28, no. 2, pp. 185-201, 1999.

[13] K. Gibson, "English only court cases involving the U.S. workplace: The myths of language use and the homogenization of bilingual 
worker's identities," Second Language Studies, vol. 22, no. 2, pp. 1-60, 2004.

[14] B. Norton, "Language and identity," in Sociolinguistics and language education, N. H. Hornberger \& S. L. Mckay, Eds. pp. 349-369, Clevedon, UK: Multilingual Matters, 2010.

[15] S. Phillipson, M. Raquel, and J. Gube, "English and its role in Hong Kong cultural identity," in Linguistic Diversity and Cultural Identity: A Global Perspective, T. Le \& Q. Le, Eds. pp. 1-12, New York: Nova Science Publishers, 2010.

[16] J. Cummins, Language, Power and Pedagogy: Bilingual Children in the Crossfire, Clevedon: Multilingual Matters, 2000.

[17] J. Cummins, "The cross-lingual dimensions of language proficiency: Implications for bilingual education and the optimal age issue," TESOL Quarterly, vol. 14, no. 2, pp. 175-187, 1980.

[18] A. Huerta-Macias and K. Kephart, "Reflections on native language use in adult ESL classrooms," Adult Basic Education and Literacy Journal, vol. 3, no. 2, pp. 87-96, 2009.

[19] O. Garcia, Forward. Disinventing and Reconstituting Languages, Clevedon, UK: Multilingual Matters, 2007.

[20] A. Creese and A. Blackledge, "Tanslanguaging in the Bilingual Classroom: A pedagogy for learning and teaching?" The Modern Language Journal, vol. 94, no. 1, pp. 103-115, 2010.
[21] S. Hudelson and C. Faltis, "Learning English as an additional language in K-12 schools," TESOL Quarterly, vol. 28, no. 3, pp. 467-468, 1994.

[22] V. Cook, "Using the first language in the classroom," The Canadian Modern Language Review, vol. 57, pp. 402-423, 2001.

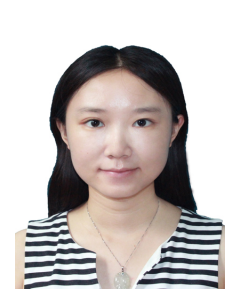

Siqi Song was born in Wuhan, China in 1991. She graduated from University of Pennsylvania in Philadelphia, US in 2015, with master degree in TESOL. She earned her bachelor of arts degree in Wuhan University in China in 2013, and her major of study was English language and literature, and she had a dual-degree in journalism.

Her current job is English lecturer in Hubei University of Technology in Wuhan, China. She used to work in US as Chinese Instructor in Pandatree Inc., First Philadelphia Chinese School, and as English teacher in Philadelphia Holy Redeemer Catholic Church ESL program. She is interest in various topics in applied linguistics and ESL teaching. 